\title{
Integration of Schools and Madrassa into Pesantren in Indonesia
}

\author{
Istikomah Istikomah \\ Fakultas Agama Islam \\ Universitas Muhammadiyah Sidoarjo \\ Sidoarjo, Indonesia \\ istikomah@umsida.ac.id
}

\author{
Eni Fariyatul Fahyuni \\ Fakultas Agama Islam \\ Universitas Muhammadiyah Sidoarjo \\ Sidoarjo, Indonesia
}

\author{
Imam Fauji \\ Fakultas Agama Islam \\ Universitas Muhammadiyah Sidoarjo \\ Sidoarjo, Indonesia
}

\begin{abstract}
Pesantren is an Islamic educational institution has its own specificity and different from other educational institutions, because the pesantren as the oldest institution in Indonesia. Originally this pesantren only teaches religious education, but starting the 20th century has been modernizing by integrating schools or madrasa inside. The integration model includes institutional, managerial, curriculum, student and finance. This research was conducted in two big pesantren in East Java Indnesia. This type of research is qualitative with data collection through observation, interview and documentation. Data were analyzed inductively. The result of the research concludes that the background of school and madrasa integration into pesantren among others, eliminates the image of pesatren which was originally as a traditional and non-qualified educational institution, now a qualified educational institution. The pesantren, which originally had no formal legality in the form of certificate, now it is the same as schools or madrasa, and to erode the dichotomy of science.
\end{abstract}

\section{Keyword--integration; schools; madrasa; pesantren}

\section{INTRODUCTION}

Pesantren is a religious educational institution with the main purpose to create people who are religious experts. Pesantrens have different characteristics from other educational systems caused by the culture that must be maintained as well as the standard teaching method with the main basis of the Qur'an, Hadith and Ijtihad Ulama [1].There are two types of pesantrens in Indonesia, namely kholaf dan salaf. Named pesantren kholaf (modern) because the curriculum has been adjusted with the government, so the results are equivalent to the school. While salaf (traditional) pesantren only teaches religious material, and regards that general lessons are not important. Such a view finaly leads to the dichotomy of science, it considers studying the knowledge of religios is obligatory, while the general knowledge is sunnah. Thus it is no dichotomy of science in Islam, but it happens dialogue. The idea of scientific integration in Islam is now is being pursued by Islamic educational thinkers. Early emergence of the idea of integration of science backed by the existence of dualism or scientific dichotomy between general science on the side and the science of religion on the other one, whereas in Islam the source of knowledge is only one that is revelation

[2].Existence of the dichotomy of science also gave birth to the dichotomic education system. The dichotomic form of education in Indonesia is the existence of educational institutions of pesantren, madrasa and schools that have different patterns and systems [3]. Pesantren focus on religious studies, while the school only examines general education. The first system gave birth to the traditional Muslim group, while the second system would give birth to modern Westernized Muslim groups [4]. While the madrasa in a position to combine both.

Islam does not recognize the dichotomy of science, the vision of Islam is tauhid which does not know the separation between religious education and general education. The main source of knowledge in Islam is the revelation received by the prophet Muhammad from God. The Qur'an as a miracle serves to guide people to the right way [5]. Islam as a perfect religion, comprehensive, universal, and high appreciation to people who seek knowledge. From the above problems, this research will answer the formulation of problems related to the background of the integration of schools and madrasas into pesantren and the integration model applied. There have been many previous studies in pesantren, but this research is very useful to reveal the motivation of pesantren to integrate with school or madrasa. The final result of this research is to publicize that pesantren is not a traditional educational institution, but has become a prestigious educational institution with excellent quality and entered into national education system.

\section{METHODS}

This research is a type of qualitative that has several characteristics among others; takes place in a natural setting, researchers as instruments primary data collector. The data analysis is done by inductive approach. In qualitative research more trying to answer the question of 'how', so much need a lot of argumentation. In accordance with the character of the data obtained, the technique of data collection and analysis refers to a qualitativenaturalistic approach that emphasizes the meaning. The source of this research data comes from field data and library one. The field data is obtaned from two pesantrens 
in East Java that have implemented integrative education from primary to intermediate level. Field research is conducted in the middle of 2016. While the other data in the form of articles, papers, and books. Data collection techniques used include; participant observation, in-depth interviews, and documentation. To ensure the accuracy of the data obtained and their compatibility with the research problem, it is necessary to examine the authenticity of the document, the correctness of the document contents, and, the relevance of the document contents with the issues studied in the research. The data analysis is divided into two stages: analysis in the field, and analysis after data. The results obtained in the first stage are field notes (fieldnote) or fieldwork. The results of the analysis at this stage of the conclusion of the temporary conclusion, then developed in the second stage analysis, At this stage, all data were analyzed inductively by using descriptive qualitative analysis, by describing the various phenomenon of management and activity of integrative pesantren

\section{FINDING AND DISCUSSION}

\section{A.Integration of Science in Islam}

Islam is a religion in the world that brings mercy to followers. Islam obligate its people to study, because the Koran as a holy book is a source of knowledge and inspiration centers of various disciplines [6]. In the view of Islam knowledge is a necessary condition to achieve the happiness in the world and the hereafter. Becuse the first revelation came down to command to seek knowledge either religion or common knowledge without any dichotomes. Like the heyday of Islam the reigh Caliph Harun ar-Rashid (786-809 AD) and his son al-Ma'mun (813-833 AD). This period of knawledge is in the golden age, thus the world of Islam at that time became the center of world civilization. An effort to restore the glory of Islam, the building of knowledge must be enforced by guidline the knowledge that is not free value, but full with value for the human mindset in line with the principles in Islam. According to al-Atas, knowledge is something that comes from God that includes all the things that in learning need an active mental and spiritual readiness. Division of knowledge according to him there are two namely, makrifat and science [7]. From the division of knowledge above, it can be concluded that knowledge in Islam does not only include the knowledge of aqidah and shari'a, but also there is another knowledge that must be studied. Those are of the world and its contents. Whereas in Islamic view there are three sources of knowledge among others ; first, the healthy senses, secondly, the Qur'an and the Hadith and the third intellect (common sense and inspiration) [8].

\section{B. Kinds of educational institutions in Indonesia}

Indonesia as a predominantly muslim country, the first educational institution established was a pesanten. However, as a nation that was once colonized by other nations namely the Netherlands and Japan, the style of educational institutions so diverse as pesantren, madrasa and school.

Pesantren is an Islamic educational institution in which there are elements of kyai, santri, dormitory (residence of santri) by teaching material of classical books that aim to understand the science of Islam in detail, and practice in everyday life with moral reinforcement in the life of the community [1]. The special feature of this institution is the sense of sincerity of the santri and the Kyai. Their relationship is not just as students and teachers, but more like a child with parents. No wonder santri feel comfortable to live in pesantren though with all its simplicity. The form of the sincerity with the cost of education and living expenses are very cheap [9]. They are together farming or trading and the results are used for their living needs and physical financing institutions. From the above description that the applied management is sincere charitable and the curriculum contains religious lessons only [10].

Madrasa is one form of educational institution that has characteristics of Islam. the establishment of madrasa in Indonesia due to the pesantren responses to the modern educational institutions introduced by the Dutch colonial government, and the influence of the reforms of the Middle East. The birth of madrasa is caused by several factors among others, firstly as a manifestation of the renewal of the national education system, secondly, the graduations get the same opportunity with the public school. Thirdly, the Muslim admiration of Western education system. Thus, this type of madrasa education institution has been managed with professional management and the curriculum was determined by the government with the ratio of general knowledge $87 \%$ and religion $13 \%$

The school is a formal educational institution established by the Dutch in 1609 with the aim of producing cheap labor [11]. The style of this educational institution is secular, because initially there are no religious subjects. This Dutch-made school has kept growing until now. However, since the independence of Indonesia, school curriculum, contains Islamic religious lessons, although only about $7.5 \%$. From the description above it appears that there is a dichotomy science and educational institutions in Indonesia. To eliminate the dichotomy, a new format is needed: integration of schools and madrasa into pesantren.

\section{PRESENTATION AND DATA ANALYSIS}

This research is qualitative, then the data is obtained in the form of words. The important data related to the formulation of the problem are as follow:

a) "Background of establishment of school in pesantren"The form of salaf education that used to only prioritize religious education, then now it must be balanced with general education without eliminating identity / nature its salafiyah. Thus students or santri will get a balanced education between religion and general, and it becomes the ideal pesantren this time. 
b) Integration model implemented"

"At the beginning of this pesantren aim makes the students understand religion, so the contents of the curriculum is only religious material in the form of tauhid, ,fiqih, history of Islam and Arabic language lessons, but because of the times when students should have a certificate that was admitted by the government. Thus it's opened a school or madrasa whose curriculum teaches contains a lot of general knowledges, so that the certificate is admitted by the government. With this certificate santri can apply for a job or continue to higher education. Generally pesantren was established individually, including this one. It was establised by my wife and I, thus we are the ones who manage it. In order to follow the development of the times, pesantren now must be integrated with the school, it must be managed professionally. The components that I need to integrate are institutional, managerial, student, curriculum and finance.

\section{CONCLUSION}

Pesantren as an Islamic educational institution that was first established in Indonesia, initially it was only managed traditionally and it didn't attract many public. But in accordance with the demands of the era, it must make renewal to make the graduations can compete in the work world. This pattern of extension is done by integrating with school or madrasa. A series of integrated management are, institutional, management, curriculums, student and finance. With this kind of integration, then pesantren became a quality educational institution. And now it is in demand many people although it is high expense.

With the existence of a pesantren conducting formal education in the form of madrasa and school, then the government program in the form of 9-year compulsory education was proclaimed in 1994, so that the distribution and improvement of the quality of Indonesian national education is achieved

\section{REFERENCES}

[1] P. Nilan, "The 'spirit of education' in Indonesian Pesantren," Br. J. Sociol. Educ., vol. 30, no. 2, pp. 219-232, 2009.

[2] A. Sahlan, "Enhancement of Culture in Education: Research on Indonesian High School," Procedia Soc. Behav. Sci., vol. 143, no. 1, pp. 117-121, 2014.

[3] M. A. Abdullah, "Religion, Science, and Culture: An Integrated, Interconnected Paradigm of Science," Al-Jami'ah J. Islam. Stud., vol. 52, no. 1, p. 175, 2015.

[4] Suyatno, "Sekolah Islam Terpadu dalam Sistem Pendidikan Nasional," al-Qalam, vol. 21, pp. 110, 2015.

[5] M. K. Al-Qattan, Mabahis fi “Ulumil Qur”an. Bogor: Litera Antar Nusa, 1996.

[6] S. Keshavarz, "Quran point of view on dimensions of reflection and its indications in education system," Procedia - Soc. Behav. Sci., vol. 9, pp. 1812-1814, 2010.

[7] S. M. Naquib al-Attas, Islam and the Philosophy of Science. Kuala Lumpur: ISTAC, 1989.

[8] P. M. Antara, R. Musa, and F. Hassan, "Bridging Islamic Financial Literacy and Halal Literacy: The Way Forward in Halal Ecosystem," Procedia Econ. Financ., vol. 37, no. 16, pp. 196-202, 2016.

[9] N. K. Indrawati, "Management by Inspiration: Implementation of Transformational Leadership on Business at Pondok Pesantren*) Sunan Drajat," Procedia - Soc. Behav. Sci., vol. 115, no. Iicies 2013, pp. 79-90, 2014.

[10] Istikomah, "Reorientasi Pesantren di Era Global," Halaqa, vol. 4, p. 43, 2014.

[11]E. G. Sukoharsono, "The genesis of accounting in indonesia: the dutch colonialism in the early 17th century," Indones. J. Account. Bus. Soc., vol. 1, no. 1, pp. 4-26, 1993. 